Małgorzata Wiktorko

Muzeum Sztuki w Łodzi

\title{
Edukacja muzealna w Muzeum Sztuki w Łodzi - narracja i nawigacja
}

Wiedzę można zdobywać samemu z różnych źródeł: tradycyjnie z książek, ale i coraz częściej, korzystając z Internetu. Ale jeżeli nie posiadamy podstawowych umiejętności analizowania i segregowania wiedzy - nie wiemy, nie potrafimy odróżnić, oddzielić śmieci informacyjnych od tego, co jest ważne i istotne. Kto może nam wskazać właściwe tropy w dżungli nadmiaru informacji, przemieszanych ze sobą rzeczy ważnych i nieważnych? Jak uchronić się przed zarzucaną na nas siecią, jak uniknąć pułapek, odnaleźć drogę w labiryncie? Często niestety traktuje się Internet jako źródło wszelkiej wiedzy - jak mi powiedział pewien młody człowiek: „Wszystko jest w Googlach”. Zapominamy, że komputer, Internet to tylko narzędzia, bardzo pomocne w pozyskiwaniu informacji, ale przecież nie są one wystarczającym drogowskazem, którym możemy się kierować w życiu.

Rolę przewodnika w poznawaniu świata, w porządkowaniu, hierarchizowaniu i wartościowaniu wiedzy odgrywają najpierw rodzice, potem nauczyciele w szkole. Programy nauczania są jednak nakierowane na zaliczenie wiedzy potrzebnej do zdania egzaminu i rzadko kiedy nauczyciel widzi swój przedmiot w sposób komparatystyczny, wielowymiarowy, uwzględniający konteksty.

Właściwie prowadzona edukacja muzealna daje możliwość otwarcia na poznanie kultury lokalnej i globalnej poprzez umieszczenie danego dzieła sztuki czy zjawiska artystycznego w kontekście innych dzieł, historii sztuki, historii kultury; traktowanie dzieła sztuki jako fenomenu, znaku, który poprzez artystę i kuratora wystawy daje nam współczesny świat.

Nowe technologie, interaktywne multimedia, na przykład poprzez wirtualne muzea, mogą wzmocnić przekaz kulturowy, precyzyjnie ukazać szczegóły, detale, udostępnić globalnie to, co trudno dostępne, ale nie zastąpią bezpośredniego kontaktu z dziełem sztuki, a pośrednikiem i inicjującym dialog osobowy jest właśnie edukator muzealny, swoisty nawigator 
prowadzący przez niespokojne, ciągle zmieniające się zjawiska współczesnej sztuki i kultury.

Narracja prowadzona przez edukatora muzealnego jest bardzo potrzebna. Bezpośrednie zetknięcie z dziełem sztuki nie wystarcza. To dzięki edukatorowi powstaje możliwość wniknięcia w istotę, sens dzieła sztuki - a urozmaicona edukacja muzealna daje różne możliwości dialogu osobowego, w którym uczestnik warsztatu i prowadzący twórczo współpracują, warsztaty stają się drogą poznania, przyjemnością odkrywania tajemnic, zabawą, poruszającą emocjonalnie, pozwalają łączyć odczucia zmysłowe z poznaniem racjonalnym.

Coraz ważniejsza staje się rola muzeum w edukacji. Edukacja muzealna staje się edukacją kulturową, pomaga w holistycznym ujęciu siebie samego i pozwala rozumieć, że edukacja jest permanentna, że uczymy się całe życie.

Tak rozumiana edukacja, tzw. całożyciowa, prowadzona w muzeum dotyczy więc dzieci, młodzieży szkolnej, studentów, ludzi dorosłych i starszych z uniwersytetów III wieku - i może być prowadzona akcydentalnie, bądź, najlepiej, w ramach stałych cyklicznych spotkań.

Kolekcja muzealna daje punkt wyjścia - przede wszystkim - dla samego prowadzącego edukację muzealną - do uczenia się, do ciągłego rozszerzania i pogłębiania własnej wiedzy, rozwijania własnej wyobraźni i w końcu opracowywania pomysłów na przekazywanie wiedzy i zapoznawania z kontekstami współczesnej kultury - czyli do odgrywania, nie do końca sformalizowanej, roli edukatora muzealnego.

Muzeum Sztuki w Łodzi jest wyjątkowe poprzez to, że jako pierwsze w Europie (drugie na świecie po Nowym Jorku) od 1930 roku ma w stałej ekspozycji sztukę awangardową. Muzeum Sztuki w Łodzi powstało na bazie daru grupy a. r. - Międzynarodowej Kolekcji Sztuki Nowoczesnej. Inicjatorem daru był artysta Władysław Strzemiński, który chciał pokazać sztukę sobie współczesną, realizując ideę swojego mistrza Kazimierza Malewicza, aby tworzyć „muzea kultury artystycznej”. Ta idea pokazywania sztuki sobie współczesnej kontynuowana jest przez kolejnych dyrektorów od Ryszarda Stanisławskiego do obecnego dyrektora Jarosława Suchana.

W ms2, czyli w budynku Muzeum Sztuki w Łodzi przy ulicy Ogrodowej 19, przygotowywana jest ekspozycja „Korespondencje”. Jest to wystawa sztuki awangardowej XX i XXI wieku, gdzie będą ze sobą „korespondować” kolekcja Muzeum Sztuki w Łodzi i szwajcarska kolekcja muzealna z Berna, a wszystko to razem zostanie usytuowane w kontekstach, w labiryntach 
nowoczesnej i współczesnej kultury. Pod kierunkiem Leszka Karczewskiego pracownicy Działu Edukacji przygotowali cykl wykładów pokazujących korespondencje sztuki, komparatystyczne zjawiska sztuki w różnych kontekstach. Dział Edukacji proponuje też szlaki, wędrówki po wystawie: np. „Skradziony list - odnaleziony list”, „Miasto Sztuki - przerażenie i uwiedzenie" (prowadzone przez Małgorzatę Wiktorko). Szlaki sztuki - to nie konwencjonalne oprowadzenie po wystawie, ale meandryczna wędrówka po kontekstach kultury: prowadzący łączy wiedzę z literatury, filozofii, historii, historii sztuki i analizę dzieła sztuki. Będą też oczywiście warsztaty do wystawy, które w bezpośrednim doświadczaniu, aktywnym działaniu, pozwolą poczuć koincydencje i właśnie - „korespondencje”.

Dział Edukacji Muzeum Sztuki w Łodzi za pomocą form warsztatowych wprowadza ważne pojęcia i problemy nie tylko dla sztuki współczesnej, ale i dla szeroko rozumianej kultury współczesnej.

Próba dookreślenia istotnych dla sztuki problemów poprzez narrację - wykład i aktywne, partycypacyjne współdziałanie w warsztacie, prowadzonym, „nawigowanym” przez edukatora muzealnego, dają uczestnikowi możliwość osobistego doznania, czym jest sztuka i jakie są jej konteksty.

Chcąc podzielić się doświadczeniami pracy edukacyjnej, Dział Edukacji Muzeum Sztuki w Łodzi, przy współpracy z Pracownią Działań Muzealnych Zamku Królewskiego w Warszawie, zorganizował warsztaty szkoleniowe dla edukatorów muzealnych, pracowników działów edukacji, muzealników. Warsztaty: „Sztuka współpracy ze sztuką współczesną” odbyły się w dwóch edycjach w listopadzie 2010 i w maju 2011 roku. Podczas warsztatów dla muzealników, którzy są, lub chcą stać się, edukatorami muzealnymi, twórczo podejmowano ważne kwestie: jak patrzeć na sztukę współczesną, jak o niej mówić, jakimi metodami posługuje się edukator. Chcieliśmy pokazać, że kontakt ze sztuką współczesną, „nawigowany” przez edukatora muzealnego jest jednocześnie poznaniem kultury i wskazaniem możliwości poznania intelektualnego i zmysłowego współczesnego świata.

Najciekawszym z warsztatów, jak sądzę, okazał się: Być jak Tatarkiewicz. „Dzieje sześciu pojęć" sztuki najnowszej: kwadrat, siatka, proporcja, idea, obiekt, zdarzenie. Najpierw, poprzez narrację - wykład, następowało dookreślenie poszczególnych wymienionych problemów, czyli np. kwadrat i jego konotacje w kulturze; proporcje - moduły w wyznaczaniu granic dzieła sztuki; zawarte w dziele idee i wreszcie performatywne działanie, zdarzenia w sztuce. Egzemplifikacja narracji poprzez bezpośredni kontakt 
z dziełem sztuki na ekspozycji muzealnej i wreszcie bezpośrednie uczestnictwo, partycypacja, wspólne działanie warsztatowe, jednocześnie pozwoliły na bezpośrednie doznanie tak wydawałoby się trudnych problemów przez każdego z uczestników twórczego dialogu z edukatorem, z innymi uczestnikami, z dziełem sztuki, a za jego pośrednictwem może i z samym autorem dzieła, ale i też z autorem koncepcji wystawienniczej, kuratorem wystawy.

Ważnym doświadczeniem w pracy edukacyjnej ze sztuką współczesną prowadzonej dla dzieci w Muzeum Sztuki w Łodzi była realizacja programu „Kulturanek” (10 odcinków dla TVP Kultura, jesień 2012) na podstawie warsztatów prowadzonych w Dziale Edukacji. Muzeum Sztuki w Łodzi pokazuje przede wszystkim sztukę współczesną i dlatego zajęcia edukacyjne zawsze w jakiś sposób nawiązują do ekspozycji muzealnej. Wykorzystane $\mathrm{w}$ „Kulturanku” warsztaty są projektami autorskimi edukatorów z Działu Edukacji: Barbary Kaczorowskiej, Katarzyny Mądrzyckiej-Adamczyk, Marty Wlazeł, Agnieszki Wojciechowskiej-Sej. Natomiast w roli ekspertów występowali m.in.: Małgorzata Ludwisiak - wicedyrektor Muzeum Sztuki w Łodzi, Jarosław Lubiak i Magdalena Ziółkowska z Działu Sztuki Nowoczesnej oraz Małgorzata Wiktorko z Działu Edukacji Muzeum Sztuki w Łodzi. Opracowaniem scenariusza scalającego wszystkie odcinki „Kulturanka” zajęli się Barbara Kaczorowska i Leszek Karczewski - kierownik Działu Edukacji Muzeum Sztuki w Łodzi.

„Kulturanek” jest programem edukacyjnym o sztuce współczesnej nie tylko dla dzieci, ale, co najważniejsze, $\mathrm{z}$ aktywnym, twórczym udziałem najmłodszych. W zasadzie pracownicy Muzeum Sztuki w Lodzi pełnią jedynie funkcję „nawigatorów” i „narratorów”, a prawdziwymi odkrywcami, bohaterami podróży po sztuce współczesnej są dzieci. Być może łatwiej nam zrozumieć, odczuć sztukę współczesną, jeżeli poznajemy ją przez doświadczenia dzieci.

Edukator muzealny jest więc i narratorem, i nawigatorem, dającym pośrednie wskazania, jak poruszać się w zamkniętym, wydawałoby się, świecie współczesnej sztuki i kultury, ale i też poprzez bezpośrednią partycypację sam uczestniczy w dialogu, co daje nam wszystkim, uczestnikom „rozmowy", możliwość rozwijania wyobraźni, zaspokajania potrzeb twórczego poznawania świata. 